\title{
Receptor Recognition of Maleyl-Albumin Induces Chemotaxis in Human Monocytes
}

\author{
Margaret E. Haberland, Ronald R. Rasmussen, and Alan M. Fogelman \\ Division of Cardiology, Department of Medicine, School of Medicine, University of California, Los Angeles, California 90024
}

\begin{abstract}
We demonstrate here that the exceptionally active maleylalbumin receptor of human monocytes functions in vitro as a chemoattractant receptor. Chemotaxis of human monocytes occurs at an effective median dose of 3-4 $\mu \mathrm{M}$ maleyl-albumin, a concentration representing $1 \%$ of the total albumin in the adult human. Computerized analyses by LIGAND of the saturable binding of maleyl-albumin to human monocytes reveal two classes of binding sites, described by dissociation constants of $37 \mathrm{nM}$ and $5.3 \mu \mathrm{M}$ with maximal binding of 1.6 and $23 \mathrm{pmol}$ maleylalbumin/mg cellular protein, respectively. Chemotaxis of human monocytes thus occurs at concentrations of maleyl-albumin promoting binding to the lower-affinity sites.

We propose that conformational isomers of albumin that are chemotactic may form in vivo and that albumin, in addition to receptor-independent plasma transport functions, may also play an important role in the receptor-mediated recruitment and accumulation of phagocytic cells at sites of inflammation and injury.
\end{abstract}

\section{Introduction}

Mononuclear phagocytes play a pivotal role in inflammation and tissue repair, antineoplastic defense, as well as in immune response. The active recruitment of monocytes to sites of inflammation and tissue damage is mediated by chemoattractant molecules, including bacterial products, peptide fragments derived from complement or clotting activation, factors from other cells of the immune system, proteolytic fragments of elastin, fibronectin, and collagen, leukotrienes or other prostaglandin metabolites, and numerous small peptides of diverse origin (1).

Recent reports $(2,3)$ that monocyte chemoattractant activity is associated with albumin isolated from inflammatory sites or atherosclerotic lesions suggested to us that recognition of altered albumin may induce a chemotactic response. Other groups (4-6) have demonstrated that selective chemical modification of albumin induces receptor-mediated recognition and rapid uptake of altered albumin by macrophages. In our own studies $(7,8)$ we have demonstrated that albumin modified by maleylation, as well as conformational isomers of the maleyl-reversed

Address reprint requests to Dr. Haberland.

Received for publication 1 May 1986.

J. Clin. Invest.

(C) The American Society for Clinical Investigation, Inc.

$0021-9738 / 86 / 09 / 0827 / 05 \$ 1.00$

Volume 78, September 1986, 827-831 albumin, is recognized by two separate and distinct membrane surface receptors of human blood monocytes and macrophages derived from human monocytes in vitro: the maleyl-albumin receptor and the scavenger (acetyl-low density lipoproteins, LDL) receptor. We demonstrate here that maleyl-albumin specifically recognized by the maleyl-albumin receptor produces chemotaxis in human blood monocytes. We propose that recognition of conformational isomers of albumin by the maleylalbumin receptor may function as a general mechanism for the recruitment of phagocytes to sites of inflammation and/or atherogenesis.

\section{Methods}

Materials. Sodium [ $\left.{ }^{125} \mathrm{I}\right]$ iodide $(15 \mathrm{mCi} / \mu \mathrm{g})$ was purchased from Amersham Corp., Arlington Heights, IL. $N$-Formyl-methionyl-leucyl-phenylalanine was obtained from Sigma Chemical Co. (St. Louis, MO). All other supplies and reagents were obtained from sources previously reported (7-9).

Subjects. Normal subjects were recruited from the staff and student body at the University of California. No one received drugs that might have affected serum cholesterol levels or lipid metabolism. All had normal hematocrits, leukocyte and differential counts, serum cholesterol, and triglycerides. Informed consent was obtained in writing from each person.

Separation of cells. $500 \mathrm{ml}$ of blood was taken after an overnight fast, and the monocytes were separated from $300 \mathrm{ml}$ of venous blood by counterflow centrifugation (method BB in Fogelman et al. [10]). The cells were classified and their viability was determined as described (11).

Chemotaxis. The ability of selected molecules to produce monocyte migration was determined in a 48-well microchemotaxis chamber (Nuclepore, Pleasanton, CA) containing 25- $\mu$ l lower wells and 50- $\mu$ l upper compartments separated by a $5-\mu \mathrm{m}$ pore polyvinylpyrrolidone-free polycarbonate filter (12). Agents tested for chemotactic activity were prepared in Gey's balanced salt solution (Gibco Laboratories, Chagrin Falls, $\mathrm{OH}$ ) and $2 \%$ bovine serum albumin at $\mathrm{pH} 7.4$ (Gey's/BSA) and added to the lower wells. Freshly isolated monocytes (92-95\% purity) suspended in Gey's/BSA at a density of $10^{6}$ cells $/ \mathrm{ml}$ were placed in the upper compartments, and the chamber incubated for $90 \mathrm{~min}$ at $37^{\circ} \mathrm{C}$. Monocytes migrating to the underside of the filter, after staining with May GrunwaldGiemsa (3), were counted in ten fields of constant area per well at a magnification of $1,000 \times$. Chemotactic activity was quantitated as the mean number of migrating monocytes in triplicate samples. Gey's/BSA was included as a negative buffer control and $10 \%$ endotoxin-activated serum (13) in Gey's/BSA as a positive control.

Cell culture. Autologous serum was prepared from $200 \mathrm{ml}$ of blood as described (10). Cells were suspended in $30 \%$ autologous serum in Dulbecco's modified Eagle's medium supplemented with $24 \mathrm{mM}$ $\mathrm{NaHCO}_{3}, 10 \mathrm{mM}$ 4-(2-hydroxyethyl) 1-piperazineethanesulfonic acid, $8 \mu \mathrm{g}$ of insulin per $\mathrm{ml}, 0.25 \mu \mathrm{g}$ of fungizone per $\mathrm{ml}$ (called medium B to be consistent with our previous publications $[9,10])$. Samples $(0.5$ $\mathrm{ml}$ ) of the cell suspension containing $10^{6}$ cells were transferred to 
2.0- $\mathrm{cm}^{2}$ polystyrene wells (Falcon 3047, Falcon Labware, Oxnard, CA) and incubated for $18 \mathrm{~h}$ at $37^{\circ} \mathrm{C}$ in a humidified, $5 \% \mathrm{CO}_{2}$ incubator.

Binding assays. Prior to initiating studies, cells in culture were washed three times with 1-ml vol of Dulbecco's modified Eagle's medium containing $10 \mathrm{mM}$ 4-(2-hydroxyethyl) 1-piperazineethanesulfonic acid (medium C). Cells were chilled for $60 \mathrm{~min}$ at $4^{\circ} \mathrm{C}$ before initiating binding studies. After $3 \mathrm{~h}$ of gentle rotation on a platform $(60 \mathrm{rpm})$, the cells were sequentially washed as previously described (14). Each well then received $0.4 \mathrm{ml}$ of $0.1 \mathrm{~N}$ sodium hydroxide and after $30 \mathrm{~min}$ at $37^{\circ} \mathrm{C}$, the cellular extract was quantitatively transferred to gamma vials for determination of radioactivity. The protein content of cells solubilized by $0.1 \mathrm{~N}$ sodium hydroxide was measured by the method of Lowry et al. (15) with bovine plasma albumin as a standard.

Determination of ligand binding parameters. Initial estimates of dissociation constants $\left(K_{d}\right)$ and receptor concentrations were made by inspection of plots of [bound]/[free] versus [bound] (16). The total binding data, uncorrected for nonspecific binding, were then evaluated by the nonlinear multiparameter modeling program LIGAND described by Munson and Rodbard (17) to select the model best describing the ligand binding data and to determine the best fit binding parameters. A modified version of LIGAND was implemented on an Apple II Plus minicomputer by Mr. Robert E. Williams of the Department of Microbiology at UCLA.

Preparation and chemical modification of proteins. Human LDL (d $=1.019$ to $1.063 \mathrm{~g} / \mathrm{ml}$ ) was isolated from the serum of individual healthy human subjects by ultracentrifugation (18). LDL was modified by malondialdehyde as described (19) and dialyzed against $0.01 \mathrm{M}$ sodium phosphate, pH 7.4, $0.15 \mathrm{M}$ sodium chloride, $0.01 \%$ EDTA (buffer A).

The half-cystyl derivative of crystallized bovine plasma albumin was prepared by the method of Kind and Spencer (20) as previously described (8) and modified by maleic anhydride (21), acetic anhydride (22), reductive methylation (23), or by formaldehyde (6) by established procedures. Labeling of LDL and maleyl-albumin with ${ }^{125}$ I was performed by the method of McFarlane (24) as modified by Bilheimer et al. (25). Samples were dialyzed for $16 \mathrm{~h}$ at $4^{\circ} \mathrm{C}$ against buffer $\mathrm{A}$ prior to use.

Assays of chemical modification. The malondialdehyde adduct of LDL was quantitated by colorimetric assay with thiobarbituric acid (19). The extent of lysine modification was determined by the method of Habeeb (26) with trinitrobenzenesulfonic acid as the difference in lysyl residues of modified and unmodified protein preparations. Molar ratios were calculated assuming a total molecular weight of 500,000 for protein of LDL (27) and 68,900 for maleyl-albumin (7) after determination of the protein concentrations by the method of Lowry et al. (15). Chemical derivatization of LDL by malondialdehyde resulted in modification of $38-48 \%$ of the lysyl residues of the apo B protein; maleylation, acetylation, and reductive methylation of albumin resulted in modification of $>94 \%$, and formylation, $15 \%$, of the peptidyl lysines.

\section{Results}

We have previously demonstrated that human monocytes express a second cellular receptor for maleyl-albumin that is distinct from the scavenger receptor (8). The activity of the maleyl-albumin receptor, determined both by the cellular surface binding and the lysosomal hydrolysis of maleyl-albumin, exceeds that of the scavenger receptor by several orders of magnitude in freshly isolated human monocytes and rapidly declines within $72 \mathrm{~h}$ to approach the activity of the scavenger receptor during differentiation of the cells in vitro (8). The abilities of ligands of each of these receptors to produce enhanced migration of human monocytes were determined in a microchemotaxis assembly (12). As shown in Fig. 1, progressively increasing concentrations of maleyl-albumin produced an enhanced migration of human monocytes with an apparent median effective dose of 3-4 $\mu \mathrm{M}$ maleyl-albumin. Higher concentrations $(>10 \mu \mathrm{M})$ produced a diminished response. Based upon the response in migration of monocytes to the positive control of endotoxin-activated serum

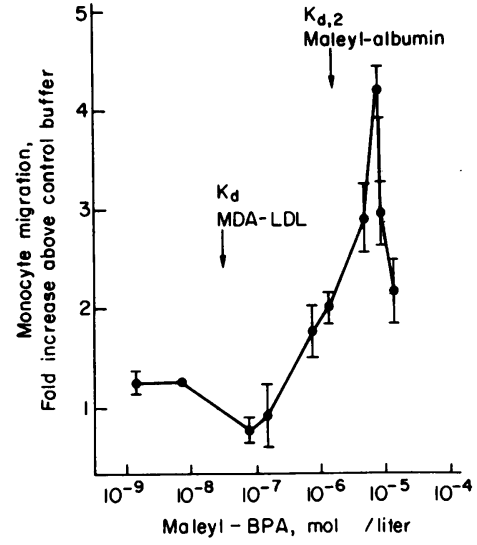

Figure 1. Dose-response curve of the migration of human blood monocytes as a function of increasing concentration of maleyl-albumin. Assays were conducted for $90 \mathrm{~min}$ at $37^{\circ} \mathrm{C}$ in a Neuroprobe 48-well microchemotaxis chamber as described in Methods. Monocytes migrating to the underside of the filter, after staining with May-Grunwald-Giemsa, were counted in ten fields of constant area per well at a magnification of $1,000 \times$. Gey's/BSA was included as a negative buffer control $(6 \pm 1$ monocytes/field) and $10 \%$ endotoxin-activated serum in Gey's/BSA as a positive control ( $36 \pm 2$ monocytes/field). Results are presented as the fold increase in monocyte migration over that obtained with Gey's/ BSA. Values shown are the mean \pm SD for triplicate determinations. The lower-affinity dissociation constants determined for maleyl-albumin from Fig. 2 and for malondialdehyde-LDL (MDA-LDL) are included for reference.

(13), maleyl-albumin was $\sim 80 \%$ as potent in inducing cellular locomotion.

Ligands of the scavenger receptor $(14,28)$, including malondialdehyde-altered human LDL (0.04-400 nM), or polyinosinic acid or fucoidin $(0.1-100 \mu \mathrm{g} / \mathrm{ml})$, failed to promote migration of human monocytes. Addition of either of these ligands or the chemoattractant $N$-formyl-methionyl-leucyl-phenylalanine $(0.1-10 \mathrm{nM})$ to the cells failed to suppress subsequent migration of the monocytes to optimal concentrations of maleylalbumin. Albumin modified by formylation (6), acetylation (8, $22)$, or reductive methylation (23), or native albumin ( $8 \mathrm{nM}-8$ $\mu \mathrm{M})$, as well as LDL (0.04-400 $\mathrm{nM}$ ) each likewise failed to promote migration. These results demonstrated that in contrast to murine peritoneal macrophages (29), human monocytes failed to migrate in response to ligands of the scavenger receptor. These findings also suggested that the enhanced migration of human monocytes evoked by maleyl-albumin was due to recognition of the ligand by the maleyl-albumin receptor.

Checkerboard analyses (30) were conducted to determine if chemotaxis or chemokinesis accounted for the observed increase in monocyte migration to maleyl-albumin. As given by a representative experiment in Table $I$, in the presence of a positive gradient of maleyl-albumin, the migration response of the monocytes increased and was concentration dependent, whereas in the presence of a negative gradient of concentration, no significant migration occurred. By these analyses it can be concluded that human monocytes recognize maleyl-albumin as a chemoattractant.

As shown in Fig. 2, the optimal chemotactic response to maleyl-albumin occurred near saturation of the cellular surface binding of the ligand to human monocytes. We have previously demonstrated that binding of maleyl-albumin to monocytes within $18 \mathrm{~h}$ after isolation is due to interaction with the maleylalbumin receptor (8). The binding data in Fig. 2 were subjected to computerized analysis by the nonlinear multiparameter LIGAND program developed by Munson and Rodbard (17). Best fit to the data was obtained by a model involving two classes of 
Table I. Checkerboard Analysis of Migration of Human Monocytes to Maleyl-Albumin*

\begin{tabular}{|c|c|c|c|c|c|}
\hline & & \multicolumn{4}{|c|}{$\begin{array}{l}\text { Maleyl-albumin, } \mu \mathrm{M} \\
\text { below filter }\end{array}$} \\
\hline & & 0 & 2.6 & 4.4 & 8.7 \\
\hline \multirow{4}{*}{$\begin{array}{l}\text { Maleyl-albumin, } \mu \mathrm{M} \\
\text { above filter }\end{array}$} & 0 & 1.0 & 3.1 & 3.5 & 4.0 \\
\hline & 2.6 & 0.9 & 1.1 & 2.4 & 2.7 \\
\hline & 4.4 & 1.0 & 1.2 & 1.0 & 1.9 \\
\hline & 8.7 & 0.9 & 1.0 & 0.9 & 1.0 \\
\hline
\end{tabular}

* Conditions are those described in Fig. 1, but with the additional inclusion of the designated concentrations of maleyl-albumin with the human monocytes $\left(10^{6} \mathrm{cells} / \mathrm{ml}\right)$ above the filter. Results are presented as the fold increase in monocyte migration over that obtained with the negative buffer control (Gey's/BSA).

binding sites ( $\mathrm{F}$ test value $=24.2$ at $P=0.0011)$. The higher affinity site was characterized by a $K_{\mathrm{d}}$ of $37 \mathrm{nM}$ with maximal binding of $1.6 \mathrm{pmol}$ of maleyl-albumin per $\mathrm{mg}$ cellular protein, and the lower affinity site by a $K_{\mathrm{d}}$ of $5.3 \mu \mathrm{M}$ with maximal binding of $23 \mathrm{pmol}$ of maleyl-albumin/mg cellular protein. Comparable values were obtained in three additional experiments conducted with monocytes from individual donors. Direct kinetic analysis of the dissociation of the bound ligand will be necessary to distinguish whether two classes of binding sites with differing affinities or differing affinities of the same receptor account for these results (31). Taken together, these data indicate that the concentrations of maleyl-albumin inducing chemotaxis correlate with the binding of the ligand to the second, lower affinity site present on human monocytes (Fig. 1).

The binding of malondialdehyde-LDL, a ligand specific for the scavenger receptor $(14,28)$, to human monocytes was also determined and was characterized by Scatchard transform as a single component (data not shown). The $K_{d}$ was determined to be $26 \mathrm{nM}$ with maximal binding of $0.11 \mathrm{pmol}$ of malondialdehyde-LDL/mg cellular protein. This value was in good agreement with the dissociation constant of $23 \mathrm{nM}$ determined by Via et al. (32) in their studies of the interaction of modified LDL with the isolated scavenger receptor of murine $\mathrm{P}_{388 \mathrm{D}_{1}}$ macrophages.

While the dissociation constants for the scavenger receptor and the higher affinity binding site of maleyl-albumin are similar, $26 \mathrm{nM}$ compared to $37 \mathrm{nM}$, respectively, the number of available binding sites differs by $\sim 14$-fold, $0.11 \mathrm{pmol}$ of malondialdehydeLDL compared to $1.6 \mathrm{pmol}$ of maleyl-albumin/mg cellular protein, respectively. If both proteins were binding to the same site, these analyses would suggest that malondialdehyde-LDL would eclipse about 14 higher-affinity maleyl-albumin binding sites. The inability of malondialdehyde-LDL to prevent the binding of maleyl-albumin (8), however, suggests that the scavenger receptor and higher affinity binding site for maleyl-albumin are separate and distinct binding sites.

\section{Discussion}

The active recruitment of phagocytes to areas of inflammation by chemotactic factors is an essential component in the maintenance of host defense mechanisms and repair to injury. In this report we have demonstrated that the exceptionally active mal-
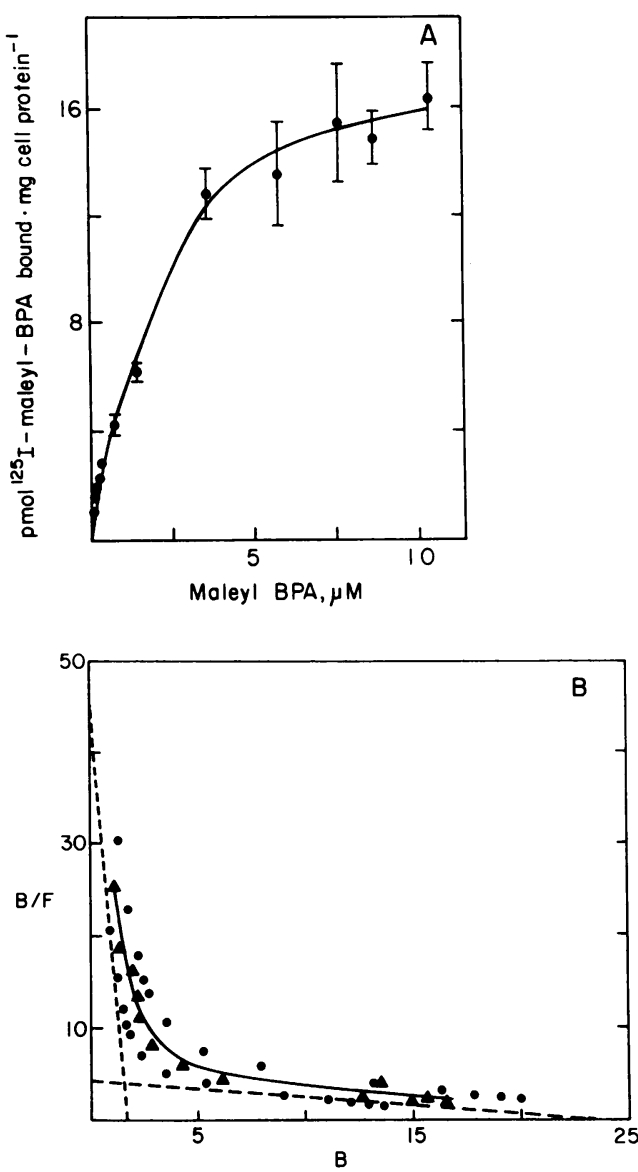

Figure 2. Binding of ${ }^{125} \mathrm{I}$-maleyl-bovine plasma albumin to human monocytes. The saturation binding profile is shown in panel $\mathrm{A}$, and the Scatchard analysis of binding is plotted in panel B. $(A)$ Normal human monocytes were cultured in $30 \%$ autologous serum in $0.5 \mathrm{ml}$ of medium $\mathrm{B}$ for $18 \mathrm{~h}$ and were prepared for binding studies at $4^{\circ} \mathrm{C}$ as described in Methods. Each well received $0.5 \mathrm{ml}$ of medium $\mathrm{C}$ containing the indicated concentrations of ${ }^{125}$ I-maleyl-bovine plasma albumin (maleyl-BPA) $(31,500 \mathrm{cpm} / \mathrm{pmol})$. After gentle rotation for $3 \mathrm{~h}$ at $4^{\circ} \mathrm{C}$, the medium was removed and the ${ }^{125} \mathrm{I}$-protein bound/mg protein was determined. $(B)$ Units for the Scatchard plot are bound (B), $\mathrm{pmol} / \mathrm{mg}$, and bound/free (B/F), pmol/mg per $\mu \mathrm{M}$. (-) presents the best fit curve to the experimental data points $(\Lambda)$ computed by LIGAND analysis \pm 2 SD (•) with a computer-derived $N$ parameter of zero for the level of nonspecific binding. The two classes of binding sites resolved by LIGAND analysis are presented as the high affinity sites (--) and low affinity sites (-- -). All values shown are the mean of quadruplicate determinations.

eyl-albumin receptor of human monocytes functions in vitro as a chemoattractant receptor. The effective median dose of maleylalbumin producing chemotaxis, $3-4 \mu \mathrm{M}$, represents $1 \%$ of the total concentration of albumin found in the adult human (33), and is consistent with interaction of the ligand with the second, lower-affinity binding site having a $K_{\mathrm{d}}$ of $5.6 \mu \mathrm{M}$.

While maleyl-albumin is also recognized by the scavenger receptor of human monocytes during differentiation in vitro (8), ligands specific for the scavenger receptor failed to produce enhanced migration of human monocytes. These results further support our previous finding (8) that the occurrence of the maleyl-albumin receptor is separate and distinct from that of the scavenger receptor. In addition, the report that ligands of the 
scavenger receptor evoke a chemotactic response in murine peritoneal macrophages (29) underscores the influence of differences in species and state of differentiation upon the observed functional responses of the monocytic cell.

We have previously demonstrated that, while human monocyte-macrophages fail to recognize native albumin by high-affinity processes, receptor-mediated recognition of albumin modified by maleylation is retained after reversal of the chemical modification (7). It has been proposed that albumin is comprised of three sequential disulfide-bonded domains, each of which is further subdivided into two subdomains (34). We have suggested that receptor binding neodeterminants in albumin arise as a consequence of conformational changes in the protein induced by maleylation and have demonstrated that this altered tertiary structure is retained after removal of the modifying maleyl groups (7). Precedence for changes in the tertiary structure of human albumin as a consequence of nonenzymatic glycosylation of a single lysyl residue has been demonstrated by Shaklai et al. (35). Taken together, these findings suggest that conformational isomers of albumin, detected either by alterations in structure (35) or in cellular receptor recognition $(7,8)$, may profoundly influence the physiological function and metabolism of albumin.

Recently two separate laboratories have reported the isolation of protein tentatively identified as albumin from early atherosclerotic lesions of hypercholesterolemic swine (3) and from aqueous humor during experimental anterior uveitis in rabbits (2) which, unlike native albumin, is chemotactic for monocytes of hypercholesterolemic swine and normal rabbits, respectively. While these investigators have concluded that albumin acted as a presumptive carrier of unidentified chemotactic agent(s) (2, 3), we suggest that receptor-mediated recognition of conformational isomers of albumin may have accounted for the observed chemotactic response.

We propose that alteration of the tertiary structure of albumin may occur in vivo at sites of atherogenesis or inflammation and that albumin, in addition to its essential receptor-independent plasma transport functions (33), may also play an important role in the receptor-mediated recruitment and accumulation of phagocytic cells at sites of inflammation and injury.

\section{Acknowledgments}

We thank Faranak Elahi, Kenneth Ho, and Dora Fong for expert technical assistance, Bonnie Streeter, Pat Ritter, and Betty Morgan for providing expertise in manuscript preparation, and Lynn Soby of the Cleveland Clinic Foundation for technical advice on the use of microchemotaxis chambers.

This work was supported by US Public Health Service grants HL 30568 and RR-865, a grant from the American Heart Association, Greater Los Angeles Affiliate (649P5), the M. K. Grey Fund, and the Laubisch Fund.

\section{References}

1. Snyderman, R., and M. C. Pike. 1984. Chemoattractant receptors on phagocytic cells. Annu. Rev. Immunol. 2:257-281.

2. Rosenbaum, J. T., and W. Raymond. 1985. Monocyte chemotactic activity induced by intravitreal endotoxin. Invest. Ophthalmol. Vis. Sci. 26:1267-1273.

3. Gerrity, R. G., J. A. Goss, and L. Soby. 1985. Control of monocyte recruitment by chemotactic factor(s) in lesion-prone areas of swine aorta. Arteriosclerosis. 5:55-66.

4. Vlassata, H., M. Brownlee, and A. Cerami. 1985. High-affinity- receptor-mediated uptake and degradation of glucose-modified proteins: a potential mechanism for the removal of senescent macromolecules. Proc. Natl. Acad. Sci. USA. 82:5588-5592.

5. Imber, M. J., S. V. Pizzo, W. J. Johnson, and D. O. Adams. 1982. Selective diminution of the binding of mannose by murine macrophages in the late stages by activation. J. Biol. Chem. 257:5129-5135.

6. Horiuchi, S., K. Takata, H. Maeda, and Y. Morino. 1985. Scavenger function of sinusoidal liver cells. J. Biol. Chem. 259:53-56.

7. Haberland, M. E., and A. M. Fogelman. 1985. Scavenger receptormediated recognition of maleyl bovine plasma albumin and the demaleylated protein in human monocyte macrophages. Proc. Natl. Acad. Sci. USA. 82:2693-2697.

8. Haberland, M. E., R. R. Rasmussen, C. L. Olch, and A. M. Fogelman. 1986. Two distinct receptors account for recognition of maleylalbumin in human monocytes during differentiation in vitro. J. Clin. Invest. 77:681-689.

9. Fogelman, A. M., J. Seager, M. Hokom, and P. A. Edwards. 1979. Separation of and cholesterol synthesis by human lymphocytes and monocytes. J. Lipid Res. 20:379-388.

10. Fogelman, A. M., M. E. Haberland, J. Seager, M. Hokom, and P. A. Edwards. 1981. Factors regulating the activities of the low density lipoprotein receptor and the scavenger receptor on human monocytemacrophages. J. Lipid Res. 22:1131-1141.

11. Fogelman, A. M., J. Edmond, J. Seager, and G. Popjak. 1975. Abnormal induction of 3-hydroxy-3-methylglutaryl coenzyme A reductase in leukocytes from subjects with heterozygous familial hypercholesterolemia. J. Biol. Chem. 250:2045-2055.

12. Falk, W., R. H. Goodwin, Jr., and E. J. Leonard. 1980. A 48 well microchemotaxis assembly for rapid and accurate measurement of leukocyte migration. J. Immunol. Methods. 33:239-247.

13. Russell, R. J., P. C. Wilkenson, R. J. McInroy, S. McKay, A. C. McCartney, and J. P. Arbuthnott. 1976. Effects of staphylococcal products on locomotion and chemotaxis of human blood neutrophils and monocytes. J. Med. Microbiol. 9:433-449.

14. Haberland, M. E., C. L. Olch, and A. M. Fogelman. 1984. Role of lysines in mediating interaction of modified low density lipoproteins with the scavenger receptor of human monocyte macrophages. J. Biol. Chem. 259:11305-11311.

15. Lowry, O. H., M. J. Rosebrough, A. L. Farr, and R. J. Randall. 1951. Protein measurement with the Folin phenol reagent. J. Biol. Chem. 193:265-275.

16. Scatchard, G. 1949. The attractions of proteins for small molecules and ions. Ann. N.Y. Acad. Sci. 51:660-672.

17. Munson, P. J., and D. Rodbard. 1980. LIGAND: A versatile computerized approach for characterization of ligand-binding systems. Anal. Biochem. 107:220-239.

18. Havel, R. J., H. A. Eder, and J. H. Bragdon. 1955. The distribution and chemical composition of ultracentrifugally separated lipoproteins of human serum. J. Clin. Invest. 43:1345-1353.

19. Haberland, M. E., A. M. Fogelman, and P. A. Edwards. 1982. Specificity of receptor-mediated recognition of malondialdehyde-modified low density lipoproteins. Proc. Natl. Acad. Sci. USA. 79:1712-1716.

20. King, T. P., and M. Spencer. 1970. Structural studies and organic ligand-binding properties of bovine plasma albumin. J. Biol. Chem. 245: 6134-6148.

21. Butler, P. J. G., and B. S. Hartley. 1972. Maleylation of amino groups. Methods Enzymol. 25B:191-199.

22. Goldstein, J. L., Y. K. Ho, S. K. Basu, and M. S. Brown. 1979. Binding site on macrophages that mediates uptake and degradation of acetylated low density lipoprotein, producing massive cholesterol deposition. Proc. Natl. Acad. Sci. USA. 76:333-337.

23. Weisgraber, K. H., T. L. Innerarity, and R. W. Mahley. 1978. Role of the lysine residues of plasma lipoproteins in high affinity binding to cell surface receptors on human fibroblasts. J. Biol. Chem. 253:90539062.

24. McFarlane, A. S. 1958. Efficient trace-labelling of proteins with iodine. Nature (Lond.). 182:53.

25. Bilheimer, D. W., S. Eisenberg, and R. I. Levy. 1972. The me- 
tabolism of very low density lipoproteins. I. Preliminary in vitro and in vivo observations. Biochim. Biophys. Acta. 260:212-221.

26. Habeeb, A. F. S. A. 1966. Determination of free amino groups in proteins by trinitrobenzenesulfonic acid. Anal. Biochem. 14:328-336.

27. Steele, J. H., Jr., and J. A. Reynolds. 1979. Molecular weight and hydrodynamic properties of apolipoprotein $\mathrm{B}$ in guanidine hydrochloride and sodium dodecyl sulfate solutions. J. Biol. Chem. 254:16391643.

28. Brown, M. S., and J. L. Goldstein. 1983. Lipoprotein metabolism in the macrophage: implications for cholesterol deposition in atherosclerosis. Annu. Rev. Biochem. 52:223-261.

29. Quinn, M. T., S. Parthasarathy, and D. Steinberg. 1985. Endothelial cell-derived chemotactic activity for mouse peritoneal macrophages and the effects of modified forms of low density lipoprotein. Proc. Natl. Acad. Sci. USA. 82:5949-5953.

30. Zigmond, S. H., and J. G. Hirsch. 1973. Leukocyte locomotion and chemotaxis. New methods for evaluation and demonstration of a cell-derived chemotactic factor. J. Exp. Med. 137:387-410.
31. Baxter, J. D., M. Schambelan, D. T. Matulich, B. J. Spindler, A. A. Taylor, and F. C. Bartler. 1976. Aldosterone receptors and the evaluation of plasma mineralocorticoid activity in normal and hypertensive states. J. Clin. Invest. 58:579-589.

32. Via, D. P., H. A. Dresel, S. L. Cheng, and A. M. Gotto, Jr. 1985. Murine macrophages tumors are a source of a 260,000 dalton acetyllow density lipoprotein receptor. J. Biol. Chem. 260:7379-7386.

33. Peters, T., Jr. 1975. Serum albumin. In The Plasma Proteins: Structure, Function, and Genetic Control. F. W. Putnam, editor. Academic Press, Inc., New York. Second ed. 1:133-181.

34. Brown, J. R., and P. Shockley. 1982. Serum albumin: structure and characterization of its ligand binding sites. In Lipid-Protein Interactions. P. C. Jost and O. H. Griffith, editors. John Wiley \& Sons, New York. 1:25-68.

35. Shaklai, N., R. L. Garlick, and H. F. Bunn. 1984. Nonenzymatic glycosylation of human serum albumin alters its conformation and function. J. Biol. Chem. 259:3812-3817. 